\title{
Belgeo
}

Revue belge de géographie

\section{Editorial. Sports Geography : an overview}

John Bale and Trudo Dejonghe

\section{(2) OpenEdition}

\section{Journals}

\section{Electronic version}

URL: https://journals.openedition.org/belgeo/10253

DOI: 10.4000/belgeo.10253

ISSN: 2294-9135

\section{Publisher:}

National Committee of Geography of Belgium, Société Royale Belge de Géographie

\section{Printed version}

Date of publication: 30 June 2008

Number of pages: 157-166

ISSN: 1377-2368

\section{Electronic reference}

John Bale and Trudo Dejonghe, "Editorial. Sports Geography : an overview", Belgeo [Online], 2 | 2008,

Online since 20 October 2013, connection on 21 September 2021. URL: http://

journals.openedition.org/belgeo/10253 ; DOl: https://doi.org/10.4000/belgeo.10253

This text was automatically generated on 21 September 2021.

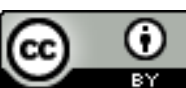

Belgeo est mis à disposition selon les termes de la licence Creative Commons Attribution 4.0 International. 


\title{
Editorial. Sports Geography : an overview
}

\author{
John Bale and Trudo Dejonghe
}

1 Geographical studies of sports are not new. The first time that sport was mentioned in a geographical publication was in 1879 when Elisée Réclus said something about cricket in his Géographie Universelle. In 1919 Hilderbrand published in the National Geographic Magazine The Geography of Games. A few years later in 1927, the German geographer Hettner (quoted in Elkins, 1989) suggested that among other things, the variations in health, hygiene, recreation and education could be "apprehended as manifestations of the nature of the land". This comment by Hettner, and earlier work by the American geographers Huntington and Semple, could also be included among environmental determinists for whom body-cultural practices were seen as perfectly legitimate fields of study (Bale, 2002). But there are hundreds of "sports" geographies. "Sports", like "Geography", is a difficult word to define and can be interpreted as a "floating signifier", available at any time and at any place for anyone to employ as they wish. It would be impossible, therefore, to review all so-called geographical work that has been authored on the topic of so-called "sports".

2 A couple of questions need to be answered before starting this short introduction to this sports geographical edition of Belgeo. Should geographical work authored by nongeographers and geographers published in all the journals and books be included? In this case space prohibits such an inclusion and we shall only deal with the works published in Geographical Journals and sport geographical books. This article is an overview of sports geographical articles in most of the Geographical journals but does not claim the title of covering all the existing articles. Only in the cases of the main sports geographical researcher John Bale will we cover some works of the main sport geographers in other journals. A broader review, including sports-geographical work by non-Geographers can be found elsewhere (Bale, 2000 ; Dejonghe, 2001a). A second point to raise is that unlike larger sub-disciplines, "sports geography" does not possess a journal of its own nor an association. It is made up of a diffuse group of scholars who 
rarely, if ever, meet. Most scholars who have written on sports would not regard sports as their specialism.

3 A decade or so after the publication of Hettner, a paper appeared in the American Journal of Educational Research by Lehrman (1940) titled The geographical origin of professional baseball players. This paper explored the wide variations between states in the "production" of top-class baseball players. The results were mapped and tentative explanations offered for the geographical pattern. It seems that this paper did not attract the interest of geographers but it was essentially the choropleth map that was to distinguish subsequent attempts to explore "the geography of sports". In the mid 1950s Jokl and his Finnish colleagues (1956) presented the findings of their research into the geographical variations in the national composition of participants in the 1952 Olympic Games. Their methodology was more statistically sophisticated than that of Lehman but again the basic approach was to seek regional variations, illustrated by graphs and statistics but critiquing the environmental determinism of earlier studies. The statistical nature of the Jokl study reflected the changes taking place in geography, i.e. the so-called "quantitative revolution" of the mid-1950s.

In 1966 Burley wrote "A note on the geography of sport" in The Professional Geographer. Burley (1966, pp. 55-56) declared that sport and more specifically home-based sport was a subject worthy of the geographer's attention because of its economic importance, its social implications, its ability to indicate cultural origins and its contribution to understanding urban land use. This note showed that sport and geography had some strong relations with other disciplines such as economics, history, sociology to mention some. The result is that even today in a lot of non-geographical journals articles with geographical dimension are published.

Scholars in the USA were not slow to recognize that the statistical nature of sports could be employed in geographical analysis. An American geographer, John Rooney, recognized the potential of sports for geographical research in the mid-1960s. Indeed, it could be argued that it was Rooney who published the first academic paper on the geography of sports in a well-respected geographical journal. His paper in the Geographical Review (Rooney, 1969) was similar in approach to that of Lehman but Rooney did not cite his work and was apparently unaware of it. Rooney's pioneering study explored the geographical variations in the production of high-class football players in the USA and their migratory patterns from high school to university. The two basic concepts that were examined were, therefore, location and migration. Such approaches not only mapped the location and migration of sports-workers; the differences in the geography of facilities and clubs were also explored. In Europe John Bale was the pioneer in the geographical studies of sport. His publication together with Gowing Geography and football : the use of ideas from football in the teaching of geography, in Teaching Geography in 1976 can be seen as the start of sport geographical publications in Europe. Bale published a great deal of articles but his book Sports Geography in 1989 and 2003, can be seen as a milestone in this discipline

While Rooney undoubtedly pioneered a geography of sports in the USA, his was not a lone voice. Rooney's work tended to lack scientific prediction in terms of, for example, the migration of athletes from one region or state to another. This is not to say that Rooney did not study migration (see Rooney, 1980) but the work of McConnell (1983) was much more sophisticated in the sense that he employed predictive techniques such as the gravity model, widely used at the time in quantitative geography. Rooney's paper 
was followed by a large number of others, using a similar methodology. Maps, tables and statistics were the prime mode of representation. Many imitations of Rooney's work were published (Bale, 1982b, 1991; Augustin, 1995 ; Ravenel, 1998a). The logical outcome of such approaches is the sports atlas and what arguably climaxed Rooney's pioneering studies was the massive Atlas of American Sport (Rooney \& Pillsbury, 1992) and an analogue contribution of the Swedish geographer Aldskogius (1993a) in the Swedish national Atlas.

7 Rooney's other major contributions to the geography of sport was the establishment of a journal, Sport and Place: An international journal of sports geography, that aimed to diffuse awareness of the geographical work in this area of study. The first issue was published in 1987 and while continuing the tradition of choropleth map-based studies also included more humanistic and interpretative papers. The final issue of Sport Place came out in 2000. The journal died for various reasons but the main ones were lack of financial support and the paucity of high quality papers that were submitted for publication. Additionally, it appeared unpredictably and faced problems with marketing. It was, in essence, a labour of love.

Rooney's other important contribution was the establishment of an annual place on the programme of the conference of the Association of American Geographers. For over a decade, Rooney inspired colleagues young and old to present papers to the conference. However, small numbers attended the "Sports Geography" sessions and geographers who saw sports studies as a part of a greater cultural geography moved in other directions, drawing on the work of colleagues in other geographical fields (i.e. humanistic, cultural and social geography) drawing on ideas from these sub-disciplines rather than sport per se. Most of the papers that followed the "choropleth" model often lacked rigour. They saw sport as simply "another thing to be mapped". Examples of the mapping approach are the articles of Yetman \& Eitzen (1973), Pillbury (1974), Gavin (1979), Shelley \& Carter (1984), Bale (1978, 1980a, 1981a, 1982b, 1983, 1989) and Adams \& Rooney $(1985,1989)$. Rooney (1974), Ojala \& Kureth (1975), Fremont (1976) and Tomlinson (1986) investigated with relative data production regions and the cores of popularity of sports in certain regions. The connection between the innovation and spatial diffusion theory of Hägerstrand and sport was very much along similar lines. The same authors wrote articles about sport as a historical-geographical innovation and took distance and economic development as the main variables of adoption. Bale \& Maquire (1994, p. 9) criticized this methodology : "The fledgling sub-discipline of 'sport geography' has tended to be locked into a time-warp of 'cartographic fetishism' and has generally failed to embrace the more recent theoretical, post positivist movement in which structuration and time-geography might be included". Dejonghe (2001a, 2001b, 2007) developed this viewpoint and argued that besides these innovation and spatial diffusion models, cultural links between country of origin and other countries, nationalism and the World-System of Wallerstein are a stronger explanation for the popularity and spread of modern sports in the world. With Rooney's retirement from Oklahoma State University in the late 1990s, "Sports geography" as a recognizable entity had faded away.

9 The humanistic geographer Ley (1985, pp. 417-418) read the Rooney-style sports geography as follows: "While the maps are of great interest and their compilation is no small task, they exemplify a research style where description takes precedence over interpretation. Maps of spatial origins of professional sports players, to take one theme, 
invite interpretive accounts of the places and practices which produced such 'social facts'". Mainstream geographers had been studying sports phenomena but published their works in more prestigious journals and attended conferences as social, political or economic geographers, rather than as students of sport per se. Two or three examples can illustrate this. One of America's most senior cultural geographers, Wagner (1981), authored a paper on the significance of geography in sport per se. The American geographer, Pred (1981) has explored dimensions of time-space in the context of nineteenth century baseball attendance as well presenting an intriguing reading of Stockholm's Globe arena (Pred, 1995). The equally well-known scholar, the late Peter Gould (1999) published several short quantitative papers on the micro-geography of sports (soccer and skiing) but would never have dreamt of calling himself a sports geographer. Likewise, the Swedish cultural geographer, Aldskogious (1993b) has explored the impact of ice-hockey on the small Swedish town of Leksand. There are numerous numbers of geographers who have taken an interest in sport on an occasional basis but the reputation of these scholars was not made by their studies of baseball, ice hockey or skiing. Arguably, it is only Rooney and Bale who have built reputations (such as they are) through sport-geographical studies.

The demise of Sport Place and the relative decline of sport-focussed geographical conferences has not meant a decline in interest among geographers of sport and bodycultural practices. Indeed, just as Rooney's "Oklahoma school" was starting to decline, cultural geography acknowledged the significance of the body (Seamon, 1979). However, this is not to say that the spatial-analytic approach has far from disappeared as we shall show. Indeed, geographers of all kinds, from humanistic to statistical and positivistic, are currently undertaking studies in sports. In the second half of this paper we will draw attention to some recent studies that are carrying on the geographical tradition of writing about sport.

11 In France Walterspeiler published in 1982 an article about the location of football teams in Lotharingen an the correlation between the level of the teams and the population of the cities and their economic activity. But in most of the cases the contributions of French geographers were examples of the existing descriptive way of working. In 1987 Mathieu \& Praicheux published with the Atlas "Sports en France" the example of descriptive cartographical sports geography. The continued interest in the "mapping" tradition is reflected in several papers published in the French journal Mappemonde, dedicated as its title suggests to mapping the world. The edition Espace du sport of 1989/2 and the article of Mathieu \& Praicheux together with Volle in the same journal in 1992 was a prolongation of these descriptive methods and is even today the main approach of sports and geography in France. The articles of Grosjean, Théry and Gay in the 2006 editions of this journal are still descriptive with little theoretical advance. The same could be said of the article that Gay published in 1997 in L'espace Géographique.

The French geographer Augustin (1995) published with his Sport, géographie et aménagement, the French sport geographical book. Augustin $(1997,1998)$ published some articles that were totally different from the other French publications. His recent publication in 2007 is another book on sports geography Géographie du sport: spatialité contemporaines et mondialisation. He still uses the descriptive way of working but we notice already a more holistic approach to his topics. A contemporary French sport geographer is the already mentioned Ravenel. His first publications in Mappemonde in 1996, in L'espace géographique in 1998 and L'information Géographique in 1998 were still 
descriptive and his book La géographie du football en France and in Norois in 2004 are also an example of the French approach.

The article in 1982 of Walterspeiler could have been the start of a new direction of sport geographical research. The relation between population size and economic performances and the level of what Dejonghe $(2001,2004)$ nowadays refers to as the consumer-oriented professional team sports could have been a main topic in spatial research. Besides Walterspeiler and Ravenel (1996, 1998a, 1998b, 1998c) in France, Bale (1982b, 1989), Connell (1985), Walker (1986) and Waylen \& Snook (1990) published similar studies for English football and the American franchise sports (basketball, baseball, American Football and ice-hockey). In the Netherlands the contribution of Volkers \& Van Dam (1992) were the first attempts to introduce sport into geography. In Australia the article of Rimmer \& Johnson (1967) covered the service areas of Australian Rules Football teams, an interesting contribution. McConnell \& McCullock (1992) introduced a model of "geographical rationalisation" of the National Football League (NFL) in the US but we had to wait for Dejonghe (1999, 2001a, 2004), Dejonghe \& Van Hoof (2006) and Ravenel \& Durand (2003) before the relationship between central place, service area and location-allocation was empirical tested by a geographer. In most of the cases economists took over the sport related research of the relation between level of the teams, attendances and the size of the local population, time distance to the stadium, economic threshold, urban hierarchy and socio-economic characteristics of the population in the catchment area of a professional sport team. In 2006 Dejonghe, Van Hoof and Kemmeren published a book on the location-allocation issue of professional football in The Netherlands.

Another topic that has been in some degree covered by geographers is the impact of sporting events or sport stadiums on a certain area. Most of the sport geographical articles on this topic described the externality effects and defined them as "nuisance fields" (Bale, 1980b, 1993, 1994, 1999) or "Locally unwanted Land Use" (Van Dam, 1998) but as in the location problems of professional sport teams this topic has been taken over by economists and spatial planners. In 1995 Bale \& Moen edited the book "The stadium and the city" with contributions of academics of all kind of disciplines. The articles of Mason \& Robins (1991), Mason \& Moncrieff (1993) and Chase \& Healey (1995) are other examples of geographical contributions to this topic. The strong relation in The Netherlands between social geography and spatial planning resulted in some spatial oriented articles on stadiums. Roosjens \& Van Dam (1996) and Van Dam (1996a, 1996b, 1998, 2000) published articles on city marketing and the relationship between football stadiums and the nuisance for local communities. The relocation and modernization of the football stadiums resulted - according to Van Dam (2000) - into a positive relationship between the population living in its vicinity and its recently built stadium, most of them located outside the agglomeration.

Because sport was seen as a part of culture geographers focussed more on the relationship between the location of sports teams in their stadium and neighbourhood and the local identity, the "topophilia" (Bale, 1989; Black \& Lloyd, 1992; Hague \& Mercer,1998). Sport was defined in this case as an expression of nationalism, regionalism or localism and Bale (1989) and Dejonghe (2001a, 2001b) read them as a reaction against the rising economic dimension of professional team sports. The organisation of the Olympic Games of 1992 in Barcelona was an interesting case for urban planners, geographers, economists and other researchers. The Games were used 
to modernise the city and to convert it from a old industrial city to a new serviceoriented modern harbour city with a lot of tourism potential (Van der Heijden, 1989; Chalkley e.a, 1992 ; Ruddijs,1993). The use of sport as a new form of geomarketing was also covered for Manchester (Law, 1994), Atlanta (Buursink, 1996), Sydney (Chalkley \& Essex, 1999).

Sport migration is another topic worthwhile of sport geographical research. The so called "foot drain" or "muscle drain" of sport talents from economically less developed sport competitions towards the rich competitions in Europe, North America and even Australia, Japan or some countries in the Middle East has been covered by Ojala \& Gatwood (1989), Bale (1989), Bale \& Maquire (1994) and Poli \& Ravenel (2005) but just like in a lot of other cases have academics from other fields taken over this issue. Van der Moortele (2003) investigated the relation between football migration and the World system of Wallerstein and added another dimension on the explanation of migration fluxes.

17 We now move to examples of more humanistic and radical studies, each of which have been published in recent years. These have been selected almost at random and simply serve to illustrate the eclectic nature of sport-geographic research at the present time. Consider two examples with the focus on cycling. The first, by the British geographer Spinney (2006) focuses on "place of sense", rather than the better-known notion of "sense of place". Spinney's paper is set around the famous mountain, experienced during the Tour de France, the Mont Ventoux. He explores the idea that human movements in and through a place, define our involvement with it and help to constitute a place. He examines the way in which the joining of cyclists and their machines (bicycles) and the resulting rhythms and kinaesthetic sensations give meaning to particular places. Spinney's aims also include the sensuous experiences of a hybrid subject/object ("the cyclist") as significant in the feelings of cyclists as moving objects.

18 A second recent geographical paper on cycling (Mackintosh \& Norcliffe, 2006) deals with the public actions of women in 1890s Canada. The authors takes one group of "public women", bourgeois cyclists, who following public scepticism obtained freedom to cycle in the streets and on country roads. The bicycle promoted individualism for women who were able to engage in female flâneurie, therefore giving respectability to the new sporting pastime.

19 A third approach is some of Bale's work (Bale, 2002) on what has been called "imaginative geographies" (Gregory, 1993). Geography is often present as factual detail-based empirical research "in the field". However, there has been a long tradition of work on the "imaginative geographies" that we carry round in our head and which frequently become institutionalised on the printed page. Basing Bale's ideas on the work of the literary scholar, Said (1991) explored the way the German and Belgian colonialists re-presented/represented a body cultural-practice found in Rwanda. It involved native people leaping over a bar and, from a European perspective this looked like "high jumping". Indeed, this is what most colonial observers called it, in spite of its only superficial similarity to the western form of sportised high-jumping. The naming of the Rwandan jumping practice (gusimbuka urukiramende) as the "high jump" symbolically claimed it for Europe (i.e. "naming as claiming") despite the fact that it lacked any of the general characteristics of western sports (Guttmann, 1978). Numerous allusions to western sports were applied to an indigenous physical activity. For 
example, colonial travelers referred to the Rwandan jumpers being recruited to participate in the Olympics, that they had champions, that they would easily break the world record, and that they were natural athletes. In other words, the colonial representations referred to a world that never existed. It was an imaginative geography. As Said (1991) put it, there is no such thing as "positive geography".

Though these kinds of "geographies of sport" are basically different from the quantitative and positivistic studies of the 1960s and 1970s it would be quite wrong to assume that "scientific" work on the geography of sport has disappeared. Far from it. The application of modern technologies as GIS is likely to be widely applied to a number of sports-geographic questions. One such study involving video technology, by Antoni Moore and his colleagues (2003) applied a problem in sport to time-geography in which they draw on the inspiration of Torsten Hägerstrand, a pioneer in time-space studies in geography. Moore and his colleagues use the "language" of Hägerstrand's time-geography and the earlier work of Gattrell and Gould (1979) to represent timespace relationships in the game of rugby. They argue that the ability of time-geography to model movements and relationships (via a video-information system) at the individual level makes it a powerful visualization tool that provides important insights into goal-oriented team sport. The quantitative and positivistic basis of much of sports geography in the 1970s and 1980s is clearly alive and well.

At the start of this review we stated that non-geographers have written a large amount of geographical work on sport. A substantial number of studies by economists, sociologists, anthropologists and others have been implicitly geographical. Subjects such as stadium relocation, environmental effects of sports, sports-worker migration and the emotional attachment of spectators to sport-place have been studies by a wide range of scholars. This journal's contents are a sure sign that geographical work on sports is in a healthy state. However, insulating ourselves as "sports geographers" will not encourage the inter-disciplinary nature of what currently constitute geographies of sports.

\section{BIBLIOGRAPHY}

ADAMS R. \& ROONEY J. (1985), “The evolution of American golf facilities”, The Geographical Review, 75, 4, pp. 419-438.

ADAMS R. \& ROONEY J. (1989), “American golf courses : a regional analysis of demand”, Sport Place, 3, 1-2, pp. 2-17.

ALDSKOGIUS H. (1993), Culture life, recreation and tourism, Swedish National Atlas, Stockholm.

ALDSKOGIUS H. (1993), Leksand, Leksand, Leksand, Hedemora, Gidlunds Bokförlag.

AUGUSTIN J.-P. (1995), Sport, Géographie et Aménagement, Paris, Nathan.

AUGUSTIN J-P. (1997), “Les territoires incertains du sport”, Cahiers de géographie du Quebec, 41, 114, décembre 1997, pp. 405-411. 
AUGUSTIN J-P. (1998), "Emergence of surfing resorts on the Aquitaine littoral”, The Geographical Review, 88, 4, pp. 587-595.

AUGUSTIN J-P. (2007), Géographie du sport : spatialité contemporaines et mondialisation, Paris, Armand Colin.

BALE J. (1978), “Geographical diffusion and the adaption of professionalism in football in England \& Wales”, Geography, 63, 3, pp. 188-197.

BALE J. (1980a), "The adoption of football in Europe : an historical-geographical perspective", Canadian Journal of History of Sport Physical, 9, 2, pp. 56-66.

BALE J. (1980b), “Football clubs as neighbours”, Town and Country Planning, 49, pp. 93-94.

BALE J. (1981a), “Cricket in pre-Victorian England \& Wales”, AREA, 13, 2, pp. 119-122.

BALE J. (1981b), “Geography, sport and geographical education”, Geography, 66, 2, pp. 104-115.

BALE J. (1982a), Sport and Place: A Geography of Sport in England, Scotland and Wales, London, Hurst.

BALE J. (1982b), “Sporthistory as innovation diffusion”, Canadian Journal of History Sport, 15, pp. 38-63.

BALE J. (1983), "Changing regional origins of occupations : the case of the professional footballers in 1950 and 1980", Geography, 68, 2, pp. 140-148.

BALE J. (1989), Sports Geography, E. \& F.N. Spon, London.

BALE J. (1990), "In the shadow of the stadium : Football grounds as urban nuissance", Geography, 75, 4, pp. 325-334.

BALE J. (1993), Sport, space and the city, Routledge, London.

BALE J. (1994), Landscape of modern sport, Leicester University Press, Leicester.

BALE J. (1999), “Sport as power : running and resistance”, in SHARP J. et al. (ed.), Entanglements of power: geographies of domination/resistance, pp. 148-163.

BALE J. (2000), "Human Geography and the study of sport”, in COAKLEY J. \& DUNNING E. (eds.), Handbook of Sports Studies, London, Sage, pp. 171-186.

BALE J. (2002), Imagined Olympian: Body Culture and Colonial Representation in Rwanda, Minneapolis, University of Minnesota Press.

BALE J. (2002), “Lassitude and latitude : Observations on sport and environmental determinism”, International Review for the Sociology of Sport, 37, 2, pp. 147-158.

BALE J. \& GOWING D. (1976), "Geography and football : the use ideas from football in the teaching of geography”, Teaching Geography, 28.

BALE J. \& MAQUIRE J. (1994) (eds.), The global sports arena: athletic talent migration in an interdependent world, Frank Cass, London.

BALE J. \& MOEN O. (1995) (eds.), The stadium and the city, Keele University Press, Keele.

BLACK J. \& LLOYD M. (1992), "Home or away? Stadia redevelopment and relocation in Scotland", Scottish Geographical Magazine, 108, 1, pp. 45-49.

BURLEY T. (1966), “A note of the geography of sport”, The Professional Geographer, 14, 1, pp. 55-56. BUURSINK J. (1996), “Groeicoalitie zet Atlanta op kaart 'Very much the place to be”, Geografie, 5, 4 , pp. 8-12. 
CHALKLEY B. \& ESSEX S. (1999), “Sydney 2000 : The 'green games”” ?, Geography, 84, 4, pp. 299-307.

CHALKLEY B. \& JONES A. \& SIMS P. (1992), "Barcelona : Olympic city”, Geography Review, 6, 1, pp. 2-4.

CHASE J. \& HEALEY M. (1995), “The spatial externality effects of football matches and rock concerts : the case of Portman Road stadium", Applied Geography, 15, pp. 18-34.

CONNELL J. (1985), "Football and regional decline : some reflections”, Geography, 70, 3, pp. 240-242.

DEJONGHE T. (1999), “Topvoetbal in het Waasland als lokalisatievraagstuk in de tertiaire sector”, BEVAS, 68,1 , pp. 165-189.

DEJONGHE T. (2001a), De noodzaak aan exogeen opgelegde economisch-geografische principes bij het professionaliseren van het door endogene factoren ontstane wereldsportstelsel : case study : het lokalisatievraagstuk van het topvoetbal in Belgie, doctoraatsverhandeling, Gent, Universiteit Gent.

DEJONGHE T. (2001b), Sport in de wereld ; ontstaan, verspreiding en evolutie, Gent, Academia Press. DEJONGHE T. (2004), "Restructuring the Belgian professional football league : a locationallocation solution", in Tijdschrift voor Economische en Sociale Geografie, 95, 1, pp. 73-88.

DEJONGHE T. (2007), The popularity of football games in the world. Is there a relation with hegemonic power?", in VAN HUFFEL N. (ed.), Van Christaller tot Wallerstein, Liber Amicorum Piet Saey, Zelzate, Nautilus Academic Books, pp. 39-50.

DEJONGHE T. \& VAN HOOF S. (2006), “Over slapende reuzen en wakkere dwergen : de geografie van het Nederlandse Betaald Voetbal”, Geografie, pp. 6-11.

DEJONGHE T., VAN HOOF S. \& KEMMEREN T. (2006), Voetballen in de kleine ruimte : een onderzoek naar de geografische marktgebieden en ruimtelijke uitbreidingsmogelijkheden voor de clubs in het Nederlandse betaald voetbal, ARKO Sports Media/WJH Mulier Instituut, Nieuwegein/'s Hertogenbosch.

ELKINS T. (1989), "Human and regional geography in the German speaking lands in the first forty years of the twentieth century", in ENTRIKEN N. AND BRUNN S. (eds.), Reflections on Richard Hartshorne's The Nature of Geography, Washington DC, Association of American Geographers, pp. 17-34.

FREMONT T. (1976), La région espace vécu, PUF, Paris.

GATRELL A. \& GOULD P. (1979), “A micro-geography of team games : graphical explorations of structural relations”, AREA, 11, 4, pp. 275-278.

GAVIN T. (1979), "Up from the mines and out from the steelworks? A study of regional variations in the production of professional football in Great Britain", South Hampshire Geographer, 11, 1, pp. 22-34.

GAY J-C. (1997), “Le sport : une mise en limites de l'activité physique”, L'espace Géographique, 26, 4 pp. 327-340.

GAY J-C. (2006), “Sur les pistes de la mondialisation”, Mappemonde, 82, 2 http:// mappemonde.mgm.fr/num10/articles/art06204.pdf.

GROSJEAN F. (2006), "Processus de diffusion du football en Franche-Comté”, Mappemonde, 81, http://mappemonde. mgm.fr/num9/articles/art06102.pdf.

GOULD P. (1999), “Skiing with Euler at Beaver Creek”, Becoming a Geographer, Syracuse, Syracuse University Press, pp. 176-185. 
GREGORY D. (1993), Geographical Imaginations, Oxford, Blackwell.

GUTTMANN A. (1978), From Ritual to Record, New York, Columbia University Press.

HAGUE E. \& MERCER J. (1998), “Geographical memory and urban identity in Scotland : Raith Rovers FC and Kirkcaldy”, Geography, 83, 2, pp. 105-116.

HILDERBRAND J. (1919), “The Geography of Games”, National Geographic Magazine, 32, 2, pp. 98-143.

JOKL E. \& KARVONEN M., KIHLBERG J., KOSKELA A. \& NORO L. (1956), Sports in the Cultural Pattern of the World, Helsinki, Institute of Occupational Health.

LAW C. (1994), “Manchester's bid for the millennium Olympic Games”, Geography, 79, 3, pp. 222-231.

LEHRMAN H. (1940), “The geographic origin of professional baseball players”, Journal of Educational Research, 34, pp. 130-138.

LEY D. (1985), “Cultural/Humanistic geography”, Progress in Human Geography, 9, pp. 415-423.

MACKINTOSH P. \& NORCLIFFE G. (2006), "Flâneurie on bicycles : acquiescence to women in public in the 1890s", Canadian Geographer, 50, 1, pp. 17-37.

MASON C. \& MONCRIEFF A. (1993), "The effect of relocation on the externality fields of football stadia : the case of St Johnstone F.C.", Scottish Geographical Magazine, 109, 2, pp. 96-105.

MASON C. \& ROBINS R. (1991), "The spatial externality fields of football stadiums : the effect of football and non football use at Kenilwortht Road, Luton", Applied Geography, 11, pp. 251-266.

MATHIEU D. \& PRAICHEUX J. (1987), Atlas de l'atlas de France : Sports en France, Fayard-Reclus, Paris.

MATHIEU D., PRAICHEUX J. \& VOLLE J-P. (1987), “Sports en France”, Mappemonde, 1992/2 http:// www.mgm.fr/ PUB/Mappe-monde/M292/SPORTS.pdf.

MCCONNELL H. (1983), “Floridians in major college football”, Florida Geographer, 12, pp. 17-31.

MC CONNELL H. \& MC CULLOCK D. (1992), "Phoenix is east of Atlanta : toward a geographical rational National Football League", Sport place, 6, 1, pp. 3-13.

MOORE A, WHIGHAM P. HOLT A., ALDRIDGE C. AND HODGE K. (2006), Sport and Time Geography: A good match?, paper presented at Spatial Information Research Centre, University of Otago, http:// eprints.otago.ac.nz/ 112/01/21_moore.pdf (accessed 7 February 2007).

OJALA C. \& GATWOOD M. (1989), “The geography of major league baseball playerproduction 1876-1988", Sport place, 3, 3, pp. 24-35.

OJALA C. \& KURETH E. (1975), "From Saskatoon to Parry Sound : a geography of skates and sticks in North America", The Geographical Survey, 4, pp. 177-198.

PILLSBURYI R. (1974), “Carolina Thunder : a geography of southers stock-car racing”, Journal of Geography, 22, 1, pp. 39-46.

POLI R. \& RAVENEL L. (2005), “Les frontières de la libre circulation dans le football européen. Vers une mondialisation des flux des joueurs ?", Espace Population Sociétés, 2, pp. 293-303.

PRED A. (1981), "Production, family, free time projects", Journal of Historical Geography, 7, pp. 3-36.

PRED A. (1995), Recognizing European Modernities, London, Routledge.

RAVENEL L. (1996), “La diffusion du football de haut niveau en France”, Mappemonde, 2, pp. 14-18. 
RAVENEL L. (1998a), La géographie du football en France, PUF, Paris.

RAVENEL L. (1998b), “Hiérarchies urbaines, hiérarchies sportives”, L'Espace Géographique, 27, 4, pp. 339-348.

RAVENEL L. (1998c), "Le football de haut niveau en France : espace et territoires", L'Information Géographique, 62, 5, pp. 233-235.

RAVENEL L. (2004), “Pourquoi n'y a-t-il pas de rugby en Normandie : un essai d'explication géographique”, Norois, 190, pp. 85-95.

RAVENEL L. \& DURAND C. (2003), “Structures urbaines et sports professionnels dans le sud-est”, Sud-Ouest Européen, 13, p. 11-24.

RECLUS E. (1879), Géographie Universelle La terre et les hommes. 4 : L'Europe du Nord-Ouest, Librairie Hachette et Cie, Paris.

RIMMER P. \& JOHNSTON R. (1967), “Areas of community interest in Victoria as indicated by competitive sport”, Australian Geographer, 10, 4, pp. 311-313.

ROONEY J. (1969), “Up from the mines and out from the prairies : some geographical implications of football in de US”, Geographical Review, LIX, 4, pp. 471-492.

ROONEY J. (1974), A geography of American sport, Addison Wesley, Reading, Massachussets.

ROONEY John (1980), The Recruiting Game, Lincoln, University of Nebraska Press.

ROONEY J. \& PILLSBURY R. (1992), Atlas of American sport, Mc Millan, New York.

ROOSJEN T. \& VAN DAM F. (1996), “Wielrennen en city-marketing : Waarom Bahamontes de Tour maar één maal won", Geografie, 5, 4, pp. 20-23.

RUDDIJS S. (1993), “De Olympische Spelen als stedelijk inhaalmanoeuvre”, Geografie, 2, 1, pp. 24-27.

SAID E. (1991), Orientalism, London, Penguin.

SEAMON D. (1979), A Geography of the Lifeworld, London, Croom Helm.

SHELLEY F. \& CARTER K. (1984), “The geography of baseball fan support in the US”, North American Culture, 1, pp. 77-95.

SPINNEY J. (2006), “A place of sense : A kinaesthetic ethnography of cyclists on Mont Ventoux", Society and Space, 24, pp. 709-32.

THÉRY H. (2006), “Football et hiérarchies urbaines au Brésil”, Mappemonde 81, http:// mappemonde.mgm.fr/num9/ articles/art06103.pdf.

TOMLINSON R. (1986), “A geography of flat-racing in Great Britain”, Geography, 71, 3, pp. 228-239.

VAN DAM F. (1996a), “Geografie en sport : een rondje langs de velden”, Geografie, 5, 4, pp. 4-7.

VAN DAM F. (1996b), “Stad en stadion in England : een tweeslachtige verhouding”, Geografie, 5, 4, pp. 14-18.

VAN DAM F. (1998), "Van lulu tot hype ? Nieuwe voetbalstadions in Nederland", Geografie, 7, 2, pp. 28-33.

VAN DAM F. (2000), "Refurbishment, redevelopment or relocation? The changing form and location of football stadiums in the Netherlands", AREA, 32, 2, pp. 133-144.

VAN DE MOORTELE K. (2003), "De migraties van profspelers in de voetbalwereld”, De Aardrijkskunde, 3-4, pp. 79-86. 
VAN DER HEIJDEN W. (1989), “Wat houdt Barcelona over na de olympische spelen ?”, Geografenkrant, oktober 1989, pp. 16-17.

VOLKERS K. \& VAN DAM F. (1992), “Zal de Goffert ooit nog kolken ? Een sportgeografische beschouwing van het betaald voetbal in Nederland", Geografie, 2, december, pp. 16-21.

WAGNER P. (1981), "Sport : Culture and Geography”, in PRED A. (ed.), Space and Time in Geography, Lund, Gleerup, pp. 85-108.

WALKER B. (1986), "The demand for professional football and the success of football league teams : some city size effects", Urban studies, 9, pp. 203-207.

WALTERSPIELER M. (1982), “Le football lorrain : L'espace géographique d'un sport régional”, Revue Géographique de l'Est, 22, 3-4, pp. 307-313.

WAYLEN P. \& SNOOK A. (1990), "Patterns of regional succes in the football league", AREA, 22, 4, pp. 353-367.

YETMAN N. \& EITZEN S. (1973), "Some social and demographic correlates of football productivity”, The Geographical Review, 63, 4, pp. 553-557.

\section{AUTHORS}

\section{JOHN BALE}

Keele University, j.r.bale@educ.keele.ac.uk

\section{TRUDO DEJONGHE}

Lessius Hogeschool - KUL, trudo.dejonghe@lessius.eu 